\title{
Pterygium as an early indicator of ultraviolet insolation: a hypothesis
}

\author{
M T Coroneo
}

'Among the many obscure points which puzzle the ophthalmic surgeon the condition of pterygium presents special difficulties; its origin, development, and its tendency to relapse and recurrence, all offer problems which are still to solve." Little has changed ${ }^{2}$ since these observations were made in 1918. The role of climate had been surmised, but in recent years quickening depletion of the ozone layer ${ }^{3}$ has focused attention on the biological consequences of increased ultraviolet insolation. There is now firm evidence that exposure to broad band ultraviolet radiation $(290-400 \mathrm{~nm})$ is associated with the development of pterygium. ${ }^{4}$ It has been predicted that a $1 \%$ increase in ultraviolet radiation would increase the incidence of pterygium by $2 \cdot 5-14 \%$ in the Australian population. ${ }^{56}$ There are compelling reasons for reexamining these consequences in the eye.

Pterygium is perhaps the most obvious of the ophthalmohelioses ${ }^{7}$ (sun-related eye conditions) and can blunt sight in several different ways. ${ }^{8}$ In essence, it represents conjunctivalisation (and therefore loss of transparency) of the cornea, usually commencing at the nasal limbus. In one study,' however, $15 \%$ of pterygia were located only temporally and in $11 \%$ of cases, pterygia were located nasally and temporally.

There are several reviews dealing with the aetiology of this condition $^{10-16}$ yet a satisfactory explanation has remained elusive. As Rosenthal ${ }^{17}$ concluded 'It has been analyzed statistically, geographically, etiologically, microscopically and chemically - yet it grows onward primarily and secondarily.'

Fuchs ${ }^{18}{ }^{19}$ invoked inclement weather, smoke, and dust and suggested that the location was related to the degree of exposure of the bulbar conjunctiva which occurs when one 'squints' under these conditions. However, it has been noted in patients with divergent strabismus and pterygium, that pterygium does not affect the divergent eye in which the nasal bulbar conjunctiva is more exposed. ${ }^{20}$

In this review, the various theories of aetiology are reexamined. An attempt will be made to explain the location and shape of pterygia as well as factors involved in an individual's susceptibility to pterygium in the light of a new hypothesis.

\section{Ultraviolet light}

There is strong circumstantial evidence that exposure to ultraviolet light is important in the aetiology of pterygium ${ }^{46} 10$ but this is not accepted universally. ${ }^{212}$ Cameron $^{10}$ pointed out that pterygium was most common between latitudes 40 degrees $\mathrm{N}$ and 40 degrees $\mathrm{S}$ and for island populations. Hence a relative 'pterygium belt' straddles the equator, paralleling local atmospheric ultraviolet energy intensity.

Ultraviolet radiation was tentatively suggested as the causative agent. However, later reports of high pterygium prevalence at high latitudes $(8.6 \%$ at 65 degrees $\mathrm{N})$ in eskimos $^{22}$ provided exceptions to the general rule. Before this, Nicholls ${ }^{23}$ found the most common ocular abnormality among Cree Indians at Norway House, Manitoba, Canada to be pterygium and considered glare as an aetiological factor.

Labrador has less than one third of the global (incident) ultraviolet B light reported for regions such as the Dahlak Islands (16 degrees $\mathrm{N}$ ) and North Cameroon (5-10 degrees N). However, ultraviolet radiation exposures may be similar in these locations if terrain reflectivity is taken into account ${ }^{24}$. It is thus of interest that the two cases of pterygium blindness were reported in an Australian aborigine ${ }^{25}$ and an eskimo. ${ }^{26}$

Confirmatory evidence for the involvement of ultraviolet radiation has been gained by examining three at risk groups: those known to be exposed to high levels of ultraviolet radiation (either outdoors or occupational); those with other diseases known to be induced by ultraviolet radiation; and subjects who may be hypersensitive to the effects of ultraviolet radiation.

The ultraviolet theory of pterygium causation is supported by studies on rural Australians ${ }^{6}$ and Japanese welders. ${ }^{27}$ In the Australian study, a strong positive correlation between climatic ultraviolet radiation and pterygium prevalence was demonstrated. Furthermore, there was a comparable prevalence in male and female aborigines and the rates were higher than for non-aborigines. This was thought to be due to the fact that non-aboriginal women in rural Australia generally spend less time out of doors than men and are well housed and able to escape from solar radiation, either direct or scattered. A case-control study of pterygium in Japanese workers, ${ }^{27}$ demonstrated that pterygium was more common in welders than in other factory workers in the same industrial city. This was associated with a high exposure to ultraviolet radiation and length of employment as a welder. However, the possibility that ocular irritation was part of the aetiology cuuld not be excluded.

Other groups in whom a high prevalence of pterygium has been reported include surfers ${ }^{28}$ and sailors. ${ }^{29}$ Such individuals are exposed to high levels of ultraviolet albedo (reflected, scattered light) and adequate ocular protection is problematic. Interestingly, Lord Nelson was troubled by bilateral pterygia and a green eyeshade was added to his admiral's cocked hat. ${ }^{30}$

Recently the case for the involvement of ultraviolet radiation in the aetiology of the anterior ophthalmohelioses has been strengthened by the work of Taylor et al who investigated the watermen of Chesapeake Bay, Maryland, USA. ${ }^{4132}$ It is relevant that they found a clear association between high personal exposure to broad band ultraviolet radiation ${ }^{4}(290$ $400 \mathrm{~nm}$ ) as well as to visible light ${ }^{31}$ and increased risk of developing pterygium. They, however, found a weaker association between these factors for pinguecula and sug- 
gested that the aetiologies of pterygium and pinguecula are likely to be different. ${ }^{4}$

Further evidence for the involvement of ultraviolet light in the aetiology of pterygium comes from the systemic associations of pterygium. These include basal cell carcinoma (BCC), ${ }^{33}$ porphyria cutanea tarda (PCT),${ }^{34}$ polymorphous light eruption, ${ }^{35}$ and xeroderma pigmentosum. ${ }^{36}$ Kerkenezov $^{33}$ was of the opinion that ultraviolet light was of importance and was also the first to observe that patients with pterygia more frequently had hyperkeratosis and/or rodent ulcers on their faces, ears, hands, and forearms (that is, sunexposed areas). Furthermore, pterygia developed about a decade before the skin conditions.

There has been renewed interest ${ }^{35}$ in the association between polymorphous light eruption (actinic prurigo) and pterygium. This common chronic photodermatosis is thought to be caused by ultraviolet $A$ radiation ${ }^{37}$ - the association with pterygium is thus consistent with the involvement of broad band ultraviolet light in pterygium aetiology. Polymorphous light eruption is said to be uncommon in Australia and it is postulated that this is because of the higher ratio of ultraviolet $B$ to ultraviolet $A$ in that country. In PCT, uroporphyrin accumulates in the tissues, is photoactivated (absorption spectrum peaks at about $400 \mathrm{~nm}$ and $500-600 \mathrm{~nm}$ ), and causes tissue damage by a number of mechanisms including free radical generation. ${ }^{34}$

Further evidence for the ultraviolet theory comes from studies of ultrastructure. ${ }^{38} \mathrm{~A}$ large component of pingueculae and pterygia is the result of newly synthesised elastic fibre precursors and abnormal maturation forms of elastic fibre (elastodysplasia) that undergo secondary degeneration (elastodystrophy). These structures are presumed to be elaborated by actinically damaged fibroblasts of the substantia propria and are morphologically similar to solar degeneration of the skin. However, elastotic degeneration is reportedly uncommon in pterygia in India. ${ }^{39}$ Several authors (see Cameron ${ }^{10}$ ), however, have found changes in the basal limbal epithelial cells. These changes may occur consistently ${ }^{40}$ and may take on a new significance in that the corneal epithelial stem cells ${ }^{41}$ are located here. Some of the more recent reports on morphology of pterygium ignore this issue as the specimens examined are surgical, not post mortem. There is thus little, if any, possibility to examine limbal structures in such surgical specimens.

On the other hand, Johnson $e a^{21}$ and Norn ${ }^{22}$ have found that while the geographic distribution of spheroidal degeneration in Labrador and Newfoundland is best explained by chronic exposure to reflected ultraviolet light; this was not so for pterygium.

Much has been made of the observation that pterygium has a high prevalence in sawmill workers in British Columbia, northern India, Taiwan, and Thailand compared with control groups in the same areas. ${ }^{9}$ This observation has been used to strengthen the importance of ocular irritation as a causative agent in pterygium formation and to play down the case for ultraviolet light (as the sawmill workers presumably work indoors). It is, however, possible that even when working indoors, these workers are exposed to albedo. It was known in $\mathrm{Kenya}^{43}$ (using the northern European complexion as an indicator) that hats should be worn indoors in houses with corrugated iron roofs and no ceilings as 'galvanised sheets did not repel all the sun's rays', or more likely resulted in high albedo exposure 'indoors'.

Although the evidence for involvement of ultraviolet light is strong, a precise mechanism by which a predominantly nasal location for pterygium occurs is lacking.

\section{Tear film and heat}

In some geographic areas where pterygia are prevalent, dust, wind, and excessive desiccation often coexist with solar glare, but these are not constant features of the external milieu in areas where pterygia are common. Tear function abnormalities have been proposed as an aetiological factor. It has been observed that a pterygium is further exacerbated by elevation of the pterygium head, dryness, and delle formation. ${ }^{44}$ No abnormalities of Schirmer's test ${ }^{45}{ }^{46}$ tear break up time, ${ }^{4647}$ or rose bengal staining of the cornea were found in eyes with pterygia compared with those without. Taylor, ${ }^{46}$ however, found that aborigines with pterygium (or climatic keratopathy) had a significant discontinuity of the marginal tear strip when compared with aborigines without these conditions. However, all the other tests of tear function in these eyes were normal and it was concluded that this disruption was secondary to a mechanical disruption of the tear film. Europeans with pterygium did not show this abnormality (however, pterygia in Europeans were smaller). This is hardly surprising, as pterygia interfere with and may destroy the nasal conjunctival fornix, the integrity of which is necessary for the maintenance of the normal tear film. Pterygium incidence is high in some areas of high humidity ${ }^{48}{ }^{49}$ where desiccation is less likely. Elliott, ${ }^{50}$ however, provided evidence that drying of the tear film by wind devitalises tissues of the medial third of the palpebral aperture and that this allows actinic radiation to damage the conjunctival and corneal epithelium and Bowman's membrane. He also pointed out that tear drying can occur in areas of high humidity if the individual is exposed to constant wind, as in the trade wind belts.

Anderson ${ }^{51}$ postulated a causal relation between temperature and pterygium. Other workers ${ }^{1248}$ have implicated infrared radiation, but the evidence for this is weak. One study ${ }^{48}$ points out that in mountainous areas which receive more ultraviolet radiation, there is no greater prevalence of pterygium and therefore infrared radiation is more likely to play a role. However, in Lima, Peru (150 metres above sea level), a pterygium prevalence rate of $31 \cdot 1 \%$ has been reported. ${ }^{52}$ While Cameron ${ }^{10}$ states that no specific biological effects have been produced by infrared radiation, it has recently been shown ${ }^{53}$ that low level heating (even $39^{\circ} \mathrm{C}$ for 1 hour) induced scleral hyperplasia with activated fibroblasts in a rabbit model.

\section{Microtrauma}

Mechanical irritation by dust particles, enhanced by the tear flow from lateral to nasal ${ }^{54}$ has been proposed as a mechanism; however, pterygia occur in dust-free areas - for example, at sea in sailors, ${ }^{2948}$ surfers, ${ }^{28}$ and in the Chesapeake Bay watermen. ${ }^{4}$

\section{Angiogenesis factor}

It has been suggested that a pterygium angiogenesis factor may exist which develops following repeated irritation at the limbus. ${ }^{55}$ The presence of this factor produces vessel ingrowth and the formation of pterygium. It may be that prolonged ultraviolet exposure causes the biological changes in Bowman's membrane ${ }^{10}$ and that altered proteins so formed could then act as an angiogenic or 'pterygiogenic' factor. It may be significant that corneal epithelial cells and not keratocytes are able to release a heat stable factor, which, in a dose dependent manner increases the proliferation of vascular endothelial cells. ${ }^{56}$

\section{Immunology}

IgE and IgG deposits in pterygium connective tissue stroma have been described. ${ }^{57}$ Plasma cell and lymphocyte infiltration were seen in the same areas as IgE and IgG. However, it 


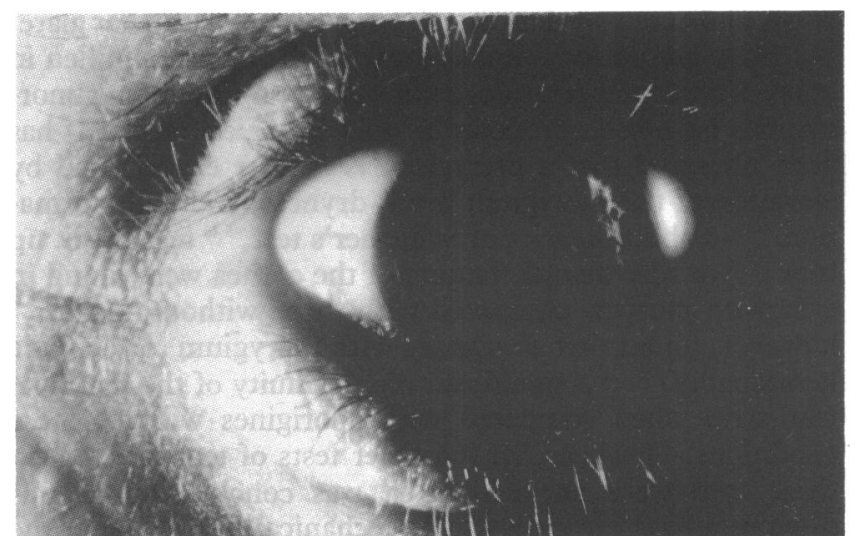

Figure 1 Light incident from a posterolateral aspect is focused by the anterior eye to the nasal limbus.

is unclear whether chronic inflammation is a cause of pterygium or a secondary finding. Certainly, chronic conjunctivitis features prominently in the early reports on this subject. ${ }^{10}$ Interestingly these authors ${ }^{57}$ speculated that cell bound IgE irritant complexes may initiate the release of active pharmacological mediators from mast cells, which may in turn release stimulatory factors leading to the development of pterygium. Suggested mediators were platelet activation factor and platelet derived growth factor. The latter regulates the effects of epidermal growth factor which has epithelial regulatory actions.

Also in the early literature is the idea that ascribes pterygium to small limbal corneal ulcers to which the conjunctiva becomes adherent - these ulcers may have been due to phlyctenulosis or herpes virus. Convincing proof for this theory is lacking.

\section{Heredity}

An inherited predisposition to pterygia seems to exist. Some pedigrees have shown an apparent transmission through several generations suggesting an autosomal dominant mode of inheritance. ${ }^{1658}$ However, this may simply reflect common environmental factors or occupations or an inherited anterior segment shape factor.

\section{Miscellaneous}

It has recently been proposed ${ }^{59}$ that a factor in adult forehead perspiration, perhaps lactic acid, commences a chain of events in pterygium formation. Sweat flows along the brow, down the side of the nose and is deposited on the nasal bulbar conjunctiva (as demonstrated by applying rose bengal to the

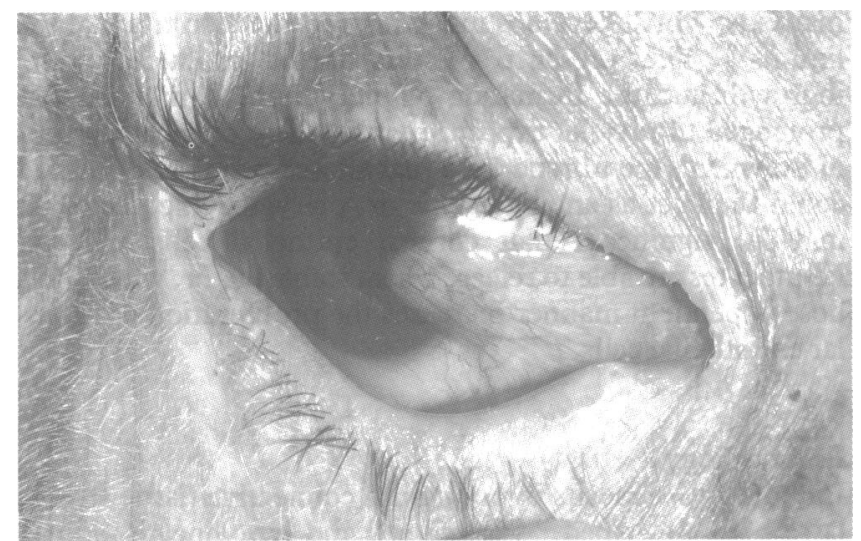

Figure 2 A fleshy pterygium at the usual nasal limbal location.

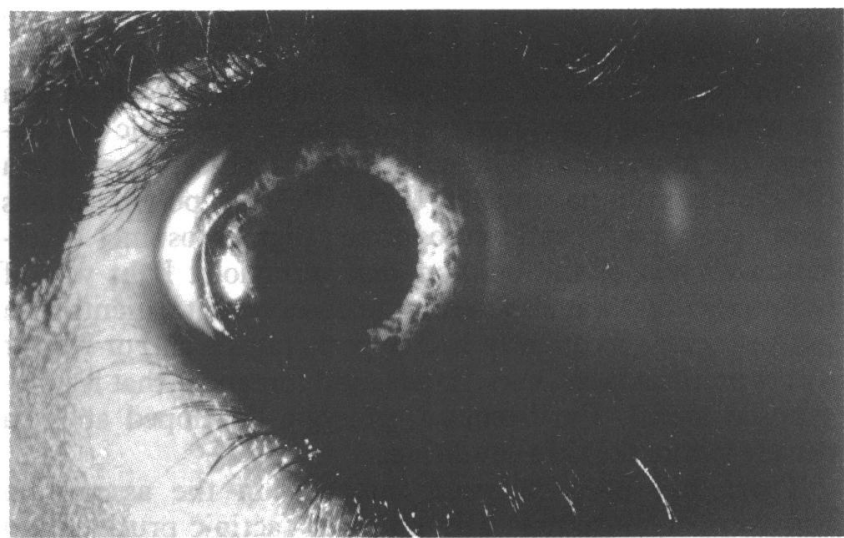

Figure 3 Light from an anterolateral aspect concentrated as a (red) glow (after passage through the nasal aspect of the crystalline lens and vascular ciliary body) behind the nasal limbus.

forehead). This theory, however, would not explain the occurrence of pterygium in situations where sweat would evaporate rapidly (as in sailors), or in cold environments where 'blinding sweat' would be unusual. Although this theory could easily be examined in experimental animals it remains untested.

Other theories which have not gained ready acceptance ${ }^{10}$ include:

(1) the notion that pterygium is due to a chronic infection;

(2) that pterygium is due to thrombosis of conjunctival veins;

(3) that contraction of the horizontal recti results in stasis in blood vessels and looseness of the conjunctiva which folds itself over the cornea forming a pterygium;

(4) that light is reflected from the skin of the nose back on to the nasal limbus.

These various theories do not provide a convincing explanation of pterygium pathogenesis, shape, or location. There is no explanation (other than inheritance) as to why only certain individuals develop pterygium in a particular environment. Unlike skin malignancy, skin pigmentation does not appear to play a role. Pterygium location has been explained by noting that the longer temporal eyelashes of the upper eyelid ${ }^{1060}$ and the greater downward 'bowing' of the outer two thirds of the upper eyelid, ${ }^{10}$ shade and filter light falling on the temporal (compared with the nasal) conjunctiva and cornea. This does not explain why temporal pterygia occur. It is not consistent with the observation ${ }^{20}$ that pterygium is found in the fixing eye of patients with exotropia where it is expected that the nasal region of the exotropic eye is more exposed. It has also been observed that pterygium develops in the dominant eye, ${ }^{60}$ probably because in intense

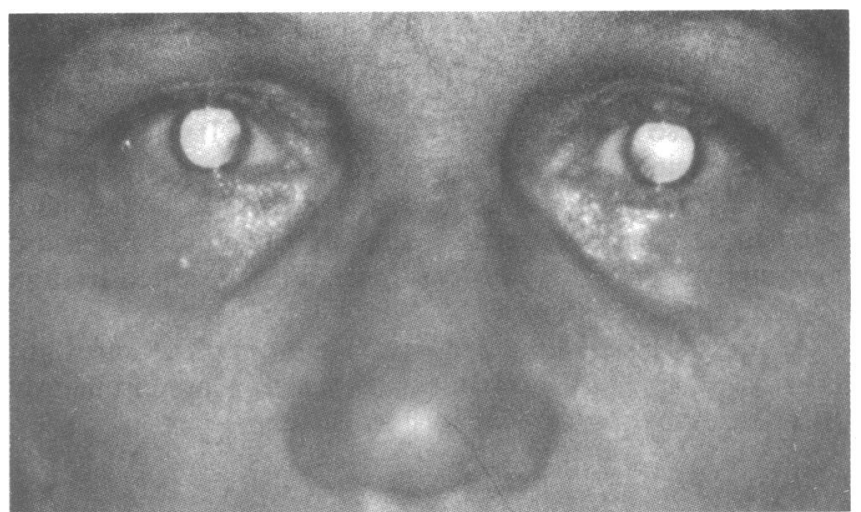

Figure 4 Bilateral cortical lens opacities seen against the red reflex in their usual initial location. 


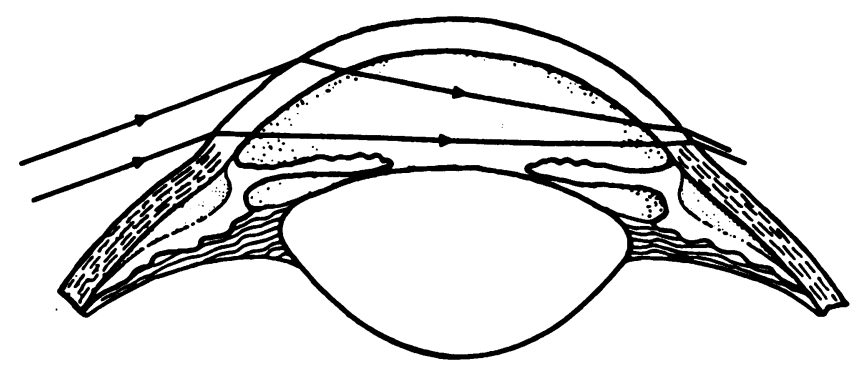

Figure 5 Proposed pathway by which peripheral refraction by the anterior eye results in a limbal focus.

sunlight the non-dominant eye is closed. These theories do not consider that the corneal epithelial stem cells, located in the basal limbal epithelium, ${ }^{41} 42$ play a role in maintaining the junction between corneal and conjunctival epithelia. ${ }^{61}$ Although it has recently been proposed ${ }^{62}$ that ptergium may be due to limbal stem cell dysfunction why this should be focal in nature remained unexplained.

\section{Hypothesis}

The ectoderm reaches sophisticated specialisation in the transparent cornea and crystalline lens. As these are the only refracting optical surfaces in the body and as indirect insolation $^{63}$ (mostly albedo) is responsible for most of the ocular ultraviolet exposure, it might be expected that the ophthalmohelioses provide early human biological warning of increased ultraviolet insolation. This indeed appears to be the case. Kerkenezov ${ }^{33}$ was the first to observe that white people with pterygia suffered from hyperkeratoses and/or rodent ulcers. Further, pterygia developed about a decade before the dermatohelioses. Subsequent prevalence data confirm this observation. ${ }^{664}$

\section{Shape and location}

An explanation for these findings has recently been proposed. ${ }^{765}$ The anterior eye acts as side on lens, focusing light from the side to the pattern of some ocular conditions thought to be caused by insolation. Thus foci are seen at the nasal limbus (Fig 1), the usual site of pterygium (Fig 2) and pinguecula, and in the nasal aspect of the crystalline lens (Fig 3 ), an initial site of cortical cataract (Fig 4). Light proceeds across the anterior eye via transcameral pathways (Figs 5 and 6). The degree of limbal focusing is determined by corneal shape and anterior chamber depth, ${ }^{7656}$ and this may explain why particular individuals in a common environment are afflicted by these conditions. As these factors are quantifiable, it may be possible to identify at risk individuals.

Using computer assisted optical ray tracing techniques, ${ }^{766}$ we have calculated that the peak light intensity at the distal limbus is approximately 20 times that of the incident light intensity. Although these focusing phenomena are easily seen with visible light, they also occur at $308 \mathrm{~nm} .{ }^{7}$ This is not unexpected as the cornea transmits significant amounts of these energetic and biologically active wavelengths $(60 \%$ of radiation at $320 \mathrm{~nm}$ and $80 \%$ at $400 \mathrm{~nm}^{67}$ ). The association of exposure to broad band ultraviolet radiation ${ }^{4}$ and visible light ${ }^{31}$ with pterygium is therefore not surprising.

Focal limbal irradiation may be particularly injurious as the corneal epithelial stem cells are struck from behind and are not protected by the more superficial layers of the epithelium. Evidence that basal limbal cells may be altered in pterygium formation was presented a century ago. ${ }^{19}$ The vertical axes of the basal cells become oblique and their regular order is lost. ${ }^{689}$ The cells become round, oblong, or distorted and there is more intense nuclear staining with haematoxylin and

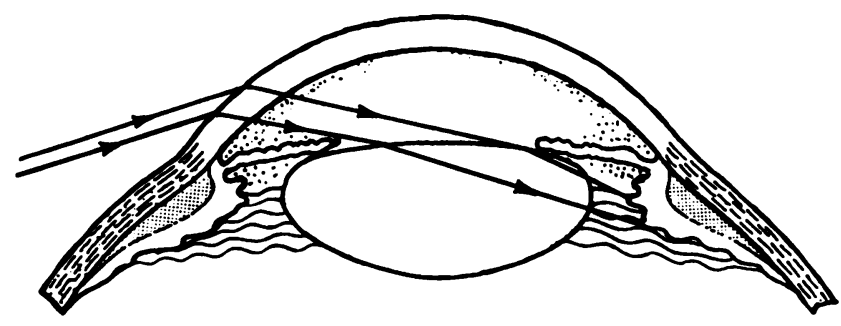

Figure 6 Proposed pathway by which peripheral refraction by the anterior eye results in concentration in the nasal crystalline lens equator.

eosin. ${ }^{69}$ Such pyknotic nuclei have been seen in lenticular epithelium which has been exposed to ultraviolet radiation. ${ }^{70}$ Recent studies, utilising surgical specimens (in which the limbus would rarely be preserved), have concentrated on changes in the stroma of the pterygium. ${ }^{38}$ Such changes may well be secondary, and as Cameron ${ }^{40}$ pointed out, these studies 'concentrated on the wrong end of the pterygium'. $\mathrm{He}$ observed 'active' fibroblasts at the head of pterygia surrounding Bowman's membrane and hypothesised that these originated in the limbal connective tissue. Recently, however, cell surface markers have been used to identify altered limbal stem cells at the edge of Bowman's layer disruption. ${ }^{71}$

Pigmentary patterns in the corneal epithelium suggest that areas of limbus contribute 'piece-of-pie' shaped areas of corneal epithelium. ${ }^{72}$ Chronic focal irradiation of the limbus may reduce the ability of that zone to renew corneal epithelium and to maintain the junction with vascularised conjunctiva ${ }^{61}$ Alternatively, ultraviolet radiation may induce hyperplasia in limbal cells as has been described for epidermal ${ }^{73}$ and hair follicle cells. ${ }^{74}$ These altered cells invade the cornea and the limbal barrier moves centripetally with them. This is consistent with evidence of abnormal proliferation of epithelium in primary pterygium. ${ }^{75}$

In either case this may explain the characteristic wing shape of pterygium (from which it derives its name). With these assumptions and by using a population balance model of corneal and limbal epithelial production, we have been able to confirm that a wing shape would be expected. ${ }^{76}$

Focal modulation of the ocular surface immune system may also play a role in pterygium formation (see Coroneo ${ }^{65}$ ). Langerhans' cells are numerous at the limbus, are depleted by ultraviolet irradiation and this is associated with immune tolerance. Two other peculiarities of pterygia may be explained by this phenomenon. Free radical generation is a prominent feature of photochemical injury. ${ }^{77}$ Free radicals stimulate mucus secretion in certain epithelia ${ }^{78}$ which may explain the intriguing observation of numerous goblet cells in pterygium epithelium. ${ }^{79}$ Secondly, tears contain lactoferrin, an iron binding protein known to inhibit free radical formation. If free radicals are being generated at the site of pterygium formation and lactoferrin plays an inhibitory role, then it is conceivable that iron is being delivered to this site and perhaps deposited there. This would account for Stocker's line of iron ${ }^{80}$ seen at the advancing edge of many pterygia.

Finally, it has long been recognised that cortical cataract often begins in the nasal aspect of the crystalline lens. ${ }^{81} 82$ These opacities may accompany pterygium ${ }^{10}$ but their presence not noted before surgery. Focal irradiation of lenticular stem cells, located at the equator of the crystalline lens, ${ }^{83}$ may cause localised lenticular opacification. ${ }^{70}$ The oblique nature of the insolation would circumvent the protection of the iris which ordinarily shields the crystalline lens equator. Furthermore, the pupil response is most sensitive to visible light (and insensitive to ultraviolet radiation ${ }^{84}$ ) and is less sensitive to peripheral retinal illumination. ${ }^{85}$ Although there has been support $^{3286}$ for the ultraviolet theory of cataractogenesis, it 
appears that the risk of cortical cataract alone is increased with exposure to ultraviolet $B .{ }^{32}$

The effect of wearing sunglasses on ocular insolation is controversial. Most sunglasses do not offer side protection from albedo, as much of the lateral conjunctiva and cornea remain exposed. Such glasses reduce glare from direct, visible light and might allow wearers to increase their exposure to ultraviolet albedo. Wearing sunglasses under extreme albedo (such as in Antarctica), can be associated with the development of photokeratitis ('snowblindness'). ${ }^{87}$ As the pupil response is most sensitive to visible light, conventional sunglasses may allow increased intraocular as well as ocular surface insolation. As suggested, ${ }^{88} 89$ wearing a hat may help but the degree of protection would be as variable as the style of hat.

These observations, while not proving that peripheral refraction phenomena cause the anterior ophthalmohelioses, provide strong circumstantial evidence for their involvement in the pathogenesis of these conditions. This conjunction of focused light (including ultraviolet) and vulnerable cells might be expected to cause accelerated pathology compared with exposure to the same levels of unfocused radiation on more resistant epidermal cells. This hypothesis provides an explanation for pterygium shape and location and may explain individual susceptibility.

Thus, increased prevalence of pterygium, a disease of the ocular surface associated with exposure to broad band ultraviolet and visible light, may provide an early indicator of increased ultraviolet insolation. In some ways the solution to the riddle of pterygium may have come to light. ${ }^{1}$

M T CORONEO

Department of Ophthalmology,

University of New South Wales,

Prince of Wales Hospital,

Randwick, New South Wales 2031,

Australia

1 Pterygium. [Editorial.] Lancet 1918; ii: 493-4.

2 Pterygium and its causes. [Editorial.] Lancet 1984; i: 1392

3 Ozone depletion quickens. [Editorial.] L ancet 1991; 337: 1132-3.

4 Taylor HR, West SK, Rosenthal FS, Muñoz B, Newland HS, Emmett EA Corneal changes associated with chronic UV irradiation. Arch Ophthalmol 1989; 107: 1481-4.

5 Favilla I. Ocular effects of ultraviolet radiation. In: Health effects of ozone layer depletion. Canberra, Australia: Australian Government Publishing Service, 1989: 96-113.

6 Moran DJ, Hollows FC. Pterygium and ultraviolet radiation: a positive correlation. BrF Ophthalmol 1984; 68: 343-6.

7 Coroneo MT, Müller-Stolzenburg NW, Ho A. Peripheral light focusing by the anterior eye and the ophthalmohelioses. Ophthalmic Surg 1991; 22: 705-11.

8 Coroneo MT. Pterygium induced nasal visual field loss: a review of pterygium related blunting of sight. Cormea (submitted).

9 Detels R, Dhir SP. Pterygium: a geographical study. Arch Ophthalmol 1967; 78: 485-91.

10 Cameron M. Pterygium throughout the world. Springfield, IL: Charles C Thomas, 1965 .

11 Jaros PA, DeLuise VP. Pingueculae and pterygia. Suro Ophthalmol 1988; 32. 41-9.

12 Pico G. Pterygium - current concepts of etiology and management. In: King $\mathrm{JH}$, McTigue JW, eds. The comea. World Congress, Washington: Butter-

13 Hill JC, Maske R. Pathogenesis of pterygium. Eye 1989; 3: 218-26.

14 Barraquer JI. Etiology, pathogenesis, and treatment of the pterygium Symposium on medical and surgical diseases of the cornea. Trans New Orleans Acad Ophthalmol. St Louis: Mosby, 1980: 167-78.

15 Kamel S. The pterygium: its etiology and treatment. Am f Ophthalmol 1954 38: $682-8$

16 Hilgers JHCh. Pterygium: its incidence, heredity and etiology. Am $\mathcal{f} O p h$ thalmol 1960; 50: 635-44.

17 Rosenthal JW. Chronology of pterygium therapy. Am $\mathcal{f}$ Ophthalmol 1953; 36: $1601-16$.

18 Fuchs E. Zur Anatomie der Pinguecula. Graefes Arch Ophthalmol 1891; 37: 143-91.

19 Fuchs E. Ueber das Pterygium. Graefes Arch Ophthalmol 1892; 38: 1-90.

20 Saad R. Pterygium, pinguecula and visual acuity. Aust f Ophthalmol 1977; 5 ; 52-66.

21 Johnson GJ, Paterson GD, Green JS, Perkins E. Ocular conditions in a Labrador community. In: Harvald B, Hart-Hansen J, eds. Proceedings of the 5th International Symposium on Circumpolar Health, Copenhagen, 1981, Report 3th International Symposium on Circumpolar Health, Copenhagen, 1981, Report

22 Norn MS. Prevalence of pinguecula in Greenland and Copenhagen and its relation to pterygium and spheroidal degeneration. Acta Ophthalmol 1979;

23 Nichols JVV. A survey of ophthalmic status of the Cree Indians at Norway House, Manitoba. Can Med Assoc F 1946; 54: 344-8.

24 Wittenberg S. Solar radiation and the eye: a review of knowledge relevant to eye care. Am f Optom Physiol Optics 1986; 63: 676-89.
25 Taylor HR, Hollows FC. Pterygium leading to blindness: a case report. Aust $\mathcal{f}$ Ophthalmol 1978; 6: 155-6.

$26 \mathrm{Fritz}$ MH. Blindness from multiple pterygiums in an Alaskan native. Am f Ophthalmol 1955; 39: 572 .

27 Karai I, Horiguchi S. Pterygium in welders. Brf Ophthalmol 1984; 68: 347-9. 28 Petersen WL. Keeping an eye out for pterygium. Surfer 1985; 26: 22-3.

29 Legwold G. Pterygium found in Olympic sailors. Phys Sports Med 1983;11: 23. 30 Pugh PDG. Nelson and his surgeons. Edinburgh: E \& S Livingstone, 1968.

31 Taylor HR, West S, Muñoz B, Rosenthal FS, Bressler SB, Bressler NM. The long-term effects of visible light on the eye. Arch Ophthalmol 1992; 110:
99-104.

32 Taylor HR, West SK, Rosenthal FS, Muñoz B, Newland HS, Abbey H, et al. Effect of ultraviolet radiation on cataract formation. NEngl f Med 1988; 319 : $1429-33$.

33 Kerkenezov N. A ptergium survey of the far north coast of New South Wales. Trans Ophthalmol Soc Aust 1956; 16: 110-9.

$34 \mathrm{Hammer} \mathrm{H}$, Korom I. Photodamage of the conjunctiva in patients with porphyria cutanea tarda. Br $\mathcal{X}$ Ophthalmol 1992; 76: 592-3.

35 Fletcher DC, Romanchuk KG, Lane PR. Conjunctivitis and pterygium associated with the American Indian type polymorphous light eruption. Can 7 Ophthalmol 1988; 23: 30-3.

$36 \mathrm{El}$-Hefnawi H, Mortada A. Ocular manifestations of xeroderma pigmentosum Br F Dermatol 1965; 77: 261-76.

37 Farr PM, Diffey BL. Adverse effects of sunscreens in photosensitive patients. Lancet 1989; i: 429-31.

38 Austin $\mathrm{P}$, Jakobiec FA, Iwamoto $\mathrm{T}$. Elastodysplasia and elastodystrophy as the pathologic bases of ocular pterygia and pinguecula. Ophthalmology 1983; 90 96-109.

39 Ansari MW, Rahi AHA, Shukla BR. Pseudoelastic nature of pterygium. Brf Ophthalmol 1970; 54: 473-6.

Mistology of pterygium: an electron microscopic study. Brf Ophthalmol 1983; 67: 604-8.

41 Davinger M, Evensen A. Role of the pericorneal papillary structure in renewal

42 Schermer A, Galvin S, Sun T-T. Differentiation-related expression of a major $64 \mathrm{~K}$ corneal keratin in vivo and in culture suggests limbal location of corneal epithelial stem cells. F Cell Biol 1986; 103: 49-62.

43 Huxley E. The flame trees of Thika. Harmondsworth: Penguin, 1985: 195.

44 Paton D. Pterygium management based upon a theory of pathogenesis. Trans Am Acad Ophthalmol Otolaryngol 1975; 79: 603-12.

45 Biedner B, Biger Y, Rothkoff L, Sachs U. Pterygium and basic tear secretion. Ann Ophthalmol 1979; 11: 1235-6.

46 Taylor HR. Studies on the tear film in climatic droplet keratopathy. Arch Ophthalmol 1980; 98: 86-8.

47 Jensen OL. Pterygium, the dominant eye and the habit of closing one eye in the sunlight. Acta Ophthalmol 1982; 60: 568-74.

48 Diponegoro RMA, Mulock-Houwer AW. A statistical contribution to the study of the aetiology of pterygium. Folia Ophthalmol Orient 1936; 2: 195-210.

49 Hilgers JHC. Pterygium: its incidence, heredity and aetiology. Am $\mathcal{F} O p h-$ thalmol 1960: 50: 635-44.

50 Elliott $R$. The aetiology of pterygium. Trans Ophthalmol Soc NZ 1961; 13: $22-41$

51 Anderson JR. A pterygium map. Acta XVII Concil Ophthalmol 1954; 3: $1631-$

52 Rojas JR, Malaga H. Pterygium in Lima, Peru. Ann Ophthalmol 1986; 18 $147-9$.

53 Finger PT, Curtin BJ, Packer S, Svitra PP, Iwamoto T, Whitmore WG, et al. Scleral hyperplasia induced by heat. Am $\mathcal{f} O$ phthalmol 1986; 102: $25-32$.

54 Elliott RH. Tropical ophthalmology. Oxford: Oxford Medical, 1920 cited by Diponegoro and Mulock-Houwer.

55 Wong WE. A hypothesis on the pathogenesis of pterygium. Ann Ophthalmol 1978; 10: 303-8.

56 Eliason JA, Elliott JP. Proliferation of vascular endothelial cells stimulated in vitro by corneal epithelium. Invest Ophthalmol Vis Sci 1987; 28: 1963-9.

57 Pinkerton OP, Yoshitsugi H, Shigemura LA. Immunologic basis for the pathogenesis of pterygium. Am $\mathcal{F}$ Ophthalmol 1984; 98: 225-8.

58 Jacklin HN. Familial predisposition to pterygium formation: a report of a family. Am $\mathcal{A}$ Ophthalmol 1964; 57: 481-2.

59 Miller D. Light and the cornea and conjunctiva. In: Miller D, ed. Clinical light damage to the eye. New York: Springer Verlag, 1987: Chapter 4, 55-63.

$60 \mathrm{Jensen} \mathrm{OL}$. Pterygium, the dominant eye and the habit of closing one eye in the sunlight. Acta Ophthalmol 1982; 60: 568-74.

61 Chen JIY, Tseng SCG. Corneal epithelial wound healing in partial limbal deficiency. Invest Ophthalmol Vis Sci 1990; 31: 1301-14.

62 Tseng SCG. Chen JJY, Huang AJW, Kruse FE, Maskin SL, Tsai RJF Classification of conjunctival surgeries for corneal diseases based on stem cell Classification of conjunctival surgeries for corneal
concept. Ophthalmol Clin N Am 1990; 3: 595-610.

63 Sliney DH. Eye protective techniques for bright light. Ophthalmology 1983;90: 937-44.

64 Green A, Beardmore G, Heart V, Leslie D, Marks R, Staines D. Skin cancer in a Queensland population. $\mathcal{A}$ Am Acad Dermatol 1988; 19: 1045-52.

65 Coroneo MT. Albedo concentration in the anterior eye: a phenomenon that locates some solar diseases. Ophthalmic Surg 1990; 21: 60-6.

66 Maloof AJ, Ho A, Coroneo MT. Anterior segment peripheral light focusing effect of incident angles and corneal shape. Invest Ophthalmol Vis Sci 1993; 34: 1251

67 Hoover HL. Solar ultraviolet irradiation of human cornea, lens, and retina: equations of ocular irradiation. Appl Optics 1986; 25: 359-68.

68 Cameron ME. Histology of pterygium: an electron microscopic study. Brf Ophthalmol 1983; 67: 604-8.

69 Cilova-Atanovsa B. Histological and histochemical changes of epithelium, basement membrane and Bowman's membrane in the avascular corneal part of pterygium. Folia Med 1968; 10: 23-6.

70 Zigman S, Vaughan T. Near-ultraviolet light effects on the lenses and retinas of mice. Invest Ophthalmol Vis Sci 1974; $13: 462-5$.

71 Dushku N, Tyler N, Reid TW. Immunohistochemical evidence that pterygia arise from altered limbal epithelial basal stem cells. Invest Ophthalmol Vis $S_{c i}$ 1993; 34: 1013 .

72 Bron AJ. Vortex patterns of the corneal epithelium. Trans Ophthalmol Soc UK

73 Blum HF. Hyperplasia induced by ultraviolet light: possible relationship to cancer induction. In: Urbach F, ed. The biologic effects of ultraviolet radiation (with emphasis on the skin). Oxford: Pergamon Press, 1969, 83-9.

74 Ley RD, Applegate LA. Hair growth induction by ultraviolet radiation in the marsupial Monodelphis domestica. Arch Dermatol 1987; 123: 1032-5. 
75 Steinemann T, Chew S, Thompson H, Wilson R, Beuerman RW. Evaluation of cellular proliferation in excised human pterygia by flow cytometry. Invest Ophthalmol Vis Sci 1992; 33 (Suppl): 772 .

$76 \mathrm{Kwok}$ LS, Coroneo MT. A model for pterygium formation. Cornea (in press).

77 Lerman S. Radiant energy and the eye. New York: Macmillan, 1980.

78 Adler KB, Akley NJ. Oxygen radicals stimulate secretion of mucin by rodent airway epithelial cells in organotypic culture. In: Cerutti PA, Fridovich I, Mlan R Liss, 1988: 101-8.

79 English FP, Yates WB, Kirkwood R, Slu S. The conjunctival goblet cells in pterygium formation. Aust $\mathcal{F}$ Ophthalmol $1980 ; 8: 53-4$.

80 Stocker F. Eine pigmentierte Hornhautlinie beim pterygium. Klin Monatsbl

Augenheilkd 1939; 102: 384-8.
81 Vogt A. Lehrbuch und Atlas. Spaltlampenmikroscopie des Lebenden Auges. Erste Teil. Technik und Methodik. Hornhaut und Vorderkammer. Berlin: Springer, 1930.
82 Taylor HR. Personal communication.

83 Rafferty NS. Lens morphology. In: Maisel H, ed. The ocular lens. New York: Marcel Dekker, 1985: 1-60.

84 Gies P, Roy CR. Ocular protection from ultraviolet radiation. Clin Exp Optom 1988; 71: 21-7.

85 Alpern M, Campbell FW. The spectral sensitivity of the consensual light reflex. f Physiol (Lond) 1962; 164: 478-507.

86 Hollows FC, Moran DJ. Cataract - the ultraviolet risk factor. Lancet 1981; 2: 1249-51.

87 Hedblom EE. Snowscape eye protection. Arch Environ Health 1961; 2: 685-704.

88 Protecting man from UV exposure. [Editorial.] Lancet 1991; 337: 1258-9.

89 Hollows FC. Ultraviolet radiation and eye diseases. Trans Menzies Foundation 1989; 15: 113-7. 